\title{
Recent Personnel Reforms of Public Universities in China and in Italy:
}

\section{A Comparison}

\author{
Sha $\mathrm{Ha}^{1}$ \\ ${ }^{1}$ School of Foreign Studies, Guangzhou University, China \\ Correspondence: Dr. Sha Ha, Assistant Professor at Guangzhou University, Address: Kelai Apartment E 21A, \\ Haizhu District, Guangzhou, China
}

Received: December 24, 2017

Accepted: January 11, 2018

Online Published: January 26, 2018

doi:10.5430/ijhe.v7n1p87

URL: https://doi.org/10.5430/ijhe.v7n1p87

\begin{abstract}
Purpose of the present research is an investigation of the most recent personnel reforms of higher education institutions in China and in Italy. A one-to-one comparison between the two realities would have been unrealistic, given the enormous differences between the two Countries in size and historical development. We focused our analysis on some basic issues common to both higher education institutions, such as the degree of the academic autonomy from the political power in the academic governance and the quality of the knowledge production and transfer to the society. The Sun Yat-Sen and the Guangzhou Universities in the Guangdong Province of China, and the Universities of Padua and Ca' Foscari in the Venetian Region of Italy, have been chosen as case studies.

In China the personnel reforms introduced by the central government in the period 1995-2014, were accompanied by a relevant financial support by the central and regional authorities, which helped the national universities to attain high standards of excellence in the technological domain. Those remarkable financial investments by the central and regional authorities are paying off, contributing to the technological advancement of the Country.

As for the Italian public universities, a very innovative reform law was introduced by the 'Ministry of Education, University and Research' in December 2010, which granted a high level of governance autonomy to those institutions. Unfortunately, the great financial crisis that hit the Country in the same period of time caused a strong reduction of the public funds to universities and a consequent brain drain of young post graduates toward Northern Europe and North America.

In spite of this temporary shortage of funds, Italian public universities have maintained their high level of excellence in science, technology and humanities, as evidenced by the increasing number of their bilateral cooperation agreements, concerning student mobility and joint research activities with foreign universities all over the world, China included.
\end{abstract}

Keywords: Personnel Reforms, Academic Autonomy, New Public Management Paradigm, Human Resources Management

\section{Introduction}

Italy and China, despite their considerable differences in size and history, have been for centuries the two main centers of irradiation of culture in the Eurasian continent. The city state of Rome, originated in central Italy in the $8^{\text {th }}$ century B.C., became at the beginning of the new millennium the center of an empire spanning from Western Europe to the Balkans, North Africa, Egypt, Syria, the Anatolian peninsula. With the collapse of the Western Roman Empire, in the $5^{\text {th }}$ century A.D., due to nomadic invasions from Northern and Eastern Europe, the spiritual heir of the Roman Emperor became the Bishop of Rome, Head of the Catholic Christian Church, whose monasteries and cathedrals became centers of knowledge. At the turn of the first millennium A.D. from those early schools originated the first modern universities of the western world, either through spontaneous initiatives of communities of 'clerici et magistri' (students and teachers), as in the case of the University of Bologna (established in 1088 A.D.) and the University of Padova (established in 1222 A.D.) or by will of monarchs, as the University of Paris (established in 1170 A.D.), the University of Cambridge (established in 1209 A.D.), the University of Naples (established in 1224 A.D.) and many others in the following centuries (Cantor,1993). As for China, over two thousand years ago the system of 'Imperial Examinations' was introduced under the Han Dynasty, with the purpose of selecting public managers, thus signing the transition from an aristocratic to a meritocratic ruling system (Fairbank, 1992). For almost 
two millennia the two higher education systems followed divergent development routes. The modern Chinese university system was born toward the end of the Qing Dynasty, in 1898, in the wake of the Hundred Days Reform by the young Guangxu Emperor, and it continued its development under the republican power, but it was interrupted with the onset of the Second Sino-Japanese War (1937-1945). With the establishment of the People's Republic of China, in October 1949, the development of the higher education system became one of the first priorities of the new government, but the forced industrialization, following Soviet Russian models, and the subsequent 'Cultural Revolution' in the Seventies, strongly conditioned that development. The 'New Course' of Chinese politics, introduced in China with the 14th Congress of the CPC, in 1992, which officially announced the establishment of a market economy 'with Chinese characteristics', stimulated a radical reform of the higher education system. As for Western Europe, the period between the signing of the 'Treaties of Rome' in April 1957, which created the 'European Coal and Steel Community' (CECA), and the establishment of the European Union (EU) in November 1993, saw the development of an intense reform of the Western European higher education system, with the purpose of creating a common European educational platform, from which descended in 1987 the 'Erasmus Project' concerning the students mobility all over the Union and, in 2006, the "Erasmus Mundus Actions', concerning the students mobility all over the world.

A one-to-one comparison between the Higher Education systems of China and Italy would have been unrealistic, given the enormous differences in size, historical development and social structure between the two Countries. The present research is focusing instead on some basic issues common to both realities, such as the academic autonomy from the political power and the implementation of a knowledge transfer from university to the society (the so called 'third mission'): the personnel reforms played a vital role in the renewal of the university system in both Countries. A related question required an answer: "Did the recent Chinese and Italian personnel reforms of public universities succeed in creating the premises for a competitive knowledge production?"

The study of the reforms of the personnel of public universities must take into account the social and economic development that characterizes the context (Whetten, 2009). According to the terminology introduced by A. S. Tsui (2006, 2007), two distinct methodological approaches have been adopted: the 'inside-out approach' (which considers the Chinese university reforms as specific to the Chinese present-day society) and the 'outside-in approach' (which interprets those reforms according to models developed in the Western World).

In China, after the $14^{\text {th }}$ Congress of the CPC, held in Beijing in October 12-18, 1992, the Central Government started a radical reform process of its Higher Education System, which is not yet concluded (Wu, 2015).

As for the Western context, the last quarter of the past millennium and the first decade of this one were characterized by the general acceptance, at a governmental level, of the so called 'New Public Management Paradigm (NPM)' (Barzelay,1999; Jones, Guthrie \& Steam, 2001), consisting in the adoption by public institutions (universities included), of organizational and operational models similar to those utilized by private enterprises. From NPM also derived the attribution to public universities of the 'third mission', consisting of knowledge transfer from universities to the society (through patents, spin offs etc.), in addition to their 'first mission' of teaching and their 'second mission' of performing scientific research.

\subsection{Literature Review}

The materials utilized in this research can be divided into:

- documents from the Chinese Communist Party, the Government of the P.R. China, the Government of Guangdong Province, the Central Administration of the Sun Yat-Sen University and the Central Administration of the Guangzhou University, available in the web as PDF files (in Chinese) (see Sections 2, 2.1, 2.2, 2.3);

- documents from the Italian 'Ministry of Education, University and Research' (Ministero dell'Istruzione, dell'Università e della Ricerca, MIUR), published in the 'Gazzetta Ufficiale', available in the web as PDF files (in Italian) (see Sections 3, 3.1, 3.2 and 3.3) and reports from the Italian Institute of Statistics (ISTAT) and the 'Federazione Lavoratori della Conoscenza - CGIL' (see Section 3.1 and Section 4);

- research papers from Chinese journals (available in the web as PDF files in Chinese or in English) (see Section 2);

- research papers on Chinese and Western University Reforms, published in International journals and reports from the European Union or other international Institutions (in English) (see Section 2 and Section 3);

- scholarly books (in English) on the History of Chinese Imperial Examinations (Fairbank, 1992) and on the History of Medieval Europe (Cantor, 1993) (see Section1). 
All these materials have been quoted in the text and listed in the Reference section.

\section{The Chinese Context}

The $14^{\text {th }}$ Central Communist Party Congress declared in 1992 that developing education was the first priority for the realization of the 'four modernizations' (modernization of agriculture, industry, national defense, science \& technology), first mentioned by Deng Xiaoping in 1978 (Evans, 1995). The science \& technology modernization implied a renewal process of the Chinese higher education system: it initiated in 1995 with the launch of the so-called 'Project 211', through which 116 'National Key Universities' were selected, with the mission of raising their research standards for the development of the Country. During the first phase of 'Project 211', lasting from 1996 to 2000, approximately USD 2.2 billion were distributed (Li, 2004). This Project was followed, in 1998, by 'Project 985', through which a subset of 38 universities (the so called 'research universities') was object of special rationalization efforts in teaching and research activities, with the goal of making them 'world-class universities', capable of affording an internationally competitive knowledge production, as can be read in the Yearbook of the Chinese Ministry of Education (Zhonghua Renmin Gongheguo Jiaoyubu, 2009). In 2011 'China's International Technology Transfer Center' (Zhōngguó Guójì Jìshù Zhuănyí Zhōngxīn) was established: as a consequence, a great number of 'academic spin-off companies', 'knowledge and industry clusters' and 'technology incubators' arose in subsequent years, as mentioned in a EU report (European Regional Development Fund, 2014). We must underline that the 'third mission' of Chinese higher education institutions is following a so-called 'Triple Helix Model', where universities, central government and regional (provincial/municipal) authorities cooperate in creating great joint ventures (Etzkowitz \& Leydesdorff, 1995). Noteworthy is the performance of the 'Tongji University Creative Cluster', where the investments from the industrial sector became the second largest source of funds in the Research \& Technology sector in Shanghai, next to investments by the central government (59\%), with a transition from an investment-driven to an innovation-driven economy growth (Ngok \& Guo, 2008; Zang, 2014; Cai \& Liu, 2015).

\subsection{Personnel Reforms at Chinese Universities}

The personnel reforms of Chinese universities were part of a more general renewal process of Public Administration, as illustrated in a paper of Xiao X. A. and Xiao B. (2013). The personnel reforms implemented by the 'national universities' followed different criteria from those adopted for 'regional, comprehensive universities'. To the 'national universities' full autonomy was granted by the central government, which only exerted a remote control on them (Ngok \& Guo, 2008; Li \& Yang, 2014; Zhou \& Xu, 2015). According to P. J. Guan (2015), a fundamental issue concerning those universities was the availability of personnel of outstanding quality: the greatest part of them is constituted by Chinese academicians having completed their scientific education in Western universities. A serious teachers awarding/revising assessment was put in place, as it will be illustrated in Section 2.2 for the Sun Yat-Sen University (SYSU).

The 'regional comprehensive universities', on the contrary, are financed by the provincial/ municipal governments and are following a pathway of reforms 'combining efficiency with fairness', according to guidelines of a law entitled 'Personnel Management Regulations of Public Institutions' (Gōnggòng Rénshì Guănlǐ Tiáolì), enacted by Premier Li Keqiang (2014) and inspired by the principles of the 'Human Resources Management (HRM)' (Xu, 2011; Holden, 2015; Lorange, 2015). Among the programmatic points of HRM there is a new distribution system of salaries and new procedures for the personnel's recruitment. The permanent employment has been reduced in number, with the greater part of staff working on the basis of an employment contract, the duration of which cannot be under 3 years. The employees are evaluated on the basis of their productivity and at the expiration of the contract their position can be maintained only according to performance. According to Yuan, Y. and Cai, X. (2015), in HRM three different aspects must be taken into consideration: the 'individual's development', the 'career development' and the' group development'. The 'individual development' comes first. The Guangzhou University (GZHU) has been chosen as a case study to illustrate the reform process at 'regional, comprehensive universities'.

\subsection{Personnel Reform at SYSU}

SYSU is a 'national university' belonging to the group of 'Project 985'. Structure and statistical data concerning this university have been retrieved from an official, annual university report (Sun Yat-Sen University, 2017, July) and can be found in Section A1 of the Appendix of this paper.

The old tenure position system of SYSU was abolished on May $29^{\text {th }}, 2005$ through the enactment of the 'Regulations for the Authorization of Teaching Staff, the Establishment of Posts and the Recruitment of Sun Yat-Sen University' (Pan, 2009). According to those regulations, each School should directly conduct each year a personnel recruitment, at home and abroad, assisted by a 'Teaching Staff Recruitment Committee', in accordance with the number of the 
teaching posts authorized by the University and the demand of the discipline's development. The employment terms of the teaching posts were subdivided into two types, a 'fixed time employment contract' (valid for 'Assistants', 'Lecturers', 'Associate Professors') and a 'non-fixed time employment contract' (tenure), valid for 'Professor'. The 'Assistants' received an initial employment contract lasting three years, with a possible renewal of three years at maximum, the 'Lecturers' have a three-year long initial employment contract and a three-year long continuing contract (with the possibility of two renewals at the utmost), the 'Associate Professors an employment contracts of three years (with possible renewals and the possibility of applying for a non-fixed time contract after the first three years).

\subsection{Personnel Reform at GZHU}

GZHU is a 'Regional Comprehensive University'. Structure and statistical data concerning GZHU have been retrieved from the official, annual University report (Guangzhou University, 2017) and can be found in Section A2 of the Appendix of this paper.

The personnel reforms at GZHU follow the guidelines of HRM, actively pursuing the policy of strengthening the construction of a high-level personnel. As mentioned in the 'Guangzhou University Yearbook' (Guangzhou Daxue, 2015, June 6: 101), at the beginning of this millennium the University gave way to a project of building up a talent team, optimizing the procedures of hiring young and middle-aged high level scientists, increasing the training efforts among the junior staff and encouraging them, through a fellowship program, to spend training periods overseas in order to get a highly qualified Ph.D.

GZHU also established a 'pilot reform' of the employment system, with an open recruitment program, an employment competition and an employment contract of 3 years at least, with a probation period of 12 months. Having worked continuously in the same unit for 10 years, a contract of employment until retirement is granted to the employees. At the end of each year an annual assessment is made about each employee, evaluating him/her as 'good', 'qualified', 'unqualified'. Staff wages include a 'basic salary', a 'performance pay' and 'allowance subsidies', reflecting job responsibilities and performance. Wages and renewal of the employment contract depend on the job's requirements, the attendance in staff training programs and the grading obtained in them. Workers enjoy social insurance benefits in accordance with the law. Rewards are given for outstanding long-term services, participation in major important national programs, technological innovation at work, significant contributions in personnel training.

\section{The Italian Context}

In Italy, the 'New Public Management Paradigm' (NPM) stimulated the enactment, by the government, of decentralization measures of the administrative functions of public institutions, thus harmonizing the Italian administrative apparatus with that of the various member states of the European Union. An administrative federalism was introduced in the various branches of public institutions, the higher education system included, granting autonomy together with the requirement of accountability. There has been a strong emphasis on selectivity in the allocation of economic and career incentives, based on the 'evaluation of performance' of the employees.

\subsection{The Reform of Italian Public Universities.}

The Italian 'Minister of Education, University and Research' Maristella Gelmini promulgated on December 30, 2010 the Law no. 240, entitled 'Rules on the organization of [public] universities and the recruitment of their personnel. Measures to stimulate the quality and efficiency of the university system' (Ministero dell'Istruzione, dell'Università e della Ricerca, 2011). According to this law, the governance body of all Italian public universities should be composed of the 'Rector' (elected by the academic and the technical/administrative staff) who represents the University and whose mandate is only for 6 years at maximum, the 'Academic Senate' (composed of 35 full professors at maximum and presided by the 'Rector'), who is responsible for the university teaching and research activities, a 'Managing Board' (composed of $40 \%$ of people external to the university and chosen by local economic institutions external to the University), a 'General Manager', who detains managing functions and presides the 'Managing Board'. The 'General Manager' is elected by the 'Managing Board', whose main duty is to assist him in preparing the 'Annual and Triennial Forecast Budget Sheet' and the 'Annual Balance Sheet' for the Ministry of Education, University and Research (MIUR), utilizing a 'unified economic-accounting system'. A 'Management Control Board', whose members are external to the university, has been also introduced: its president is chosen by the Ministry of Economy and Finance and its 3 'effective members' and 2 'alternate members', are chosen among the administrative and accounting magistrates. 
The 'Faculties' have been abolished and their institutional functions have been attributed to so called 'connecting organs', such as the 'Schools' (former Faculties) and other university organs of an administrative nature. The academic structure is subdivided into 'Departments', whose ruling organs are the 'Department Director', elected by the Department's staff among the full professors, and the 'Department Administrative Secretary', nominated by the university's 'Managing Board' and chosen among the administrative university staff external to the Department. The Department occupies a central role inside the reformed university, with teaching, research, financial and administrative autonomy, within the constraints imposed by the university's 'Administrative Board'.

The funding mechanisms of all public universities is decided by the 'Ministry of Education, University and Research' (Ministero dell'Istruzione, dell'Educazione e della Ricerca, MIUR). The university's quality of teaching and research is certified by an independent, 'National Agency for the Evaluation of the University System and Scientific Research' (Agenzia Nazionale di Valutazione dell'Università e della Ricerca, ANVUR). The financial support to the universities by the central government partly depends on these certifications.

A significant change with respect to the past has been introduced in the area of the recruitment of the academic staff through the 'Presidential Decree 222' (Ministero dell'Istruzione, dell'Università e della Ricerca, 2011), which establishes that the candidates must preliminary achieve the 'National Scientific Habilitation', delivered by a special 'National Examination Committee'. The validity period of this 'Habilitation' is 6 years.

The great part of the university staff has a permanent contract (tenure) and is subdivided into 'Researchers', 'Associate Professors' and 'Full Professors'. Another relevant part of the university staff (around 30-40\% is constituted by 'Temporary Professors' (Professori a Contratto) with an annual teaching contract' and by 'Temporary Researchers', with a triennial contract. These 'Researchers' are of two distinct types: 'Researcher with an A-type contract' (the contract has a validity of three-years and may be extended for only two years, after the successful evaluation of the teaching and research activities of the candidate), and 'Researcher with a B-type contract', whose holders draw up a three-year non-renewable contract, reserved to candidates who have been previously awarded a A-type contract or, under certain conditions, research grants. Researchers benefiting of a B-type contract and possessing the 'National Scientific Habilitation' will be evaluated by the University in the third year of validity of their contract, and, in case of positive evaluation, will be upgraded to the role of 'Associate Professors'. Because of the serious economical crisis that hit southern Europe in 2008, the turnover of the university personnel with permanent positions was dramatically reduced in Italy by about $80 \%$ in the period 2008-2015, causing a brain drain of young post graduates with Masters or Doctoral Degrees. Since 2016 the economic state of the Country is slowly improving: according to the article entitled "Italy's Economic Outlook for 2017-2018", by the Istituto Nazionale di Statistica (2017), Italy's economic outlook evidenced a 1.5 percent increase of the GDP in the year 2017, with exports growing by 4.8 percent. The estimated growth of the GDP in 2018 is about $3.3 \%$. During the period from October 2016 to January 4, 2018 the newly hired university personnel was the following: 560 'Full Professors', 631 'Associate Professors', 473 'Technical/Scientific staff with tenure', 2285 Researchers with an A-Type temporary contract, 136 Researchers with a B-Type temporary contract, 18 Technical/Scientific Staff with temporary contract (Federazione Lavoratori della Conoscenza- CGIL, 2018).

\subsection{Structure and Statistical Data of UP and CFUV}

The Personnel Reforms at UP and UCFV after 2010 have been implemented according to the 'Gelmini University Law'. Structure and statistical data concerning UP can be found in Section A3 the Appendix of this paper: they have been retrieved from an official university report for the 'Academic Year' 2015-16 (spanning from October $1^{\text {st }}, 2015$ to September 30, 2016): see (Università degli Studi di Padova, 2017).

Structure and statistical data concerning UCFV can be found in Section A4 of the Appendix of this paper: they have been retrieved from an official university report for the Academic Year 2015-16, (Università Ca' Foscari di Venezia, 2017).

\subsection{Cultural Cooperation Activities of UP and UCFV with Chinese Universities}

Since 2005 Italy is successfully cooperating with Chinese higher education institutions in research and teaching activities through the 'Erasmus Mundus' Actions, the bilateral intergovernmental agreements 'Marco Polo' and 'Turandot' and several other bilateral university agreements. In 2009 the Guangzhou University (GZHU) was the first to establish a bilateral students mobility agreement with UP. At present, 15 students and 5 academics from GZHU can yearly visit UP and, conversely, the same amount of Italian students and academics from UP can visit GZHU. The students can stay at the hosting university for 10 months and the academics can yearly teach courses and perform joint research activities with hosting colleagues for 1 month. In addition to GZHU, the following 
Chinese universities are presently involved in research activities with UP: Harbin University, Liaoning University, Northwest University (Xi'an), Beijing University of Chemical Technology, Capital Normal University (Beijing), China University of Geosciences (Beijing), Renmin University (Beijing), Tsinghua University (Beijing), Tianjin University, Dalian University of Technology, East China University of Political Sciences and Law Shanghai), Shanghai Institute of Ceramics, Shanghai Institute of Chemistry of the Chinese Academy of Sciences, Technical University (Shanghai), Hubei Institute of Technology, Hubei University, Hubei University of Technology (Hubei Province), Jiangsu University, Zhejiang Scie-Tech University, Pharmaceutical University (Nanjing), South East University (Nanjing), South China Normal University (Guangdong Province). The total number of Chinese students from GZHU or other Chinese universities (through Marco Polo fellowships) who attended undergraduate or post-graduate courses at UP in the academic year 2015/16 amounted to 148 units.

The 'Erasmus Mundus' joint Masters and PhD courses offered, in English, to international students from all over the world (Chinese students included) in the Academic Year 2015/16, were the following: 'Algant' (Algebra, Geometry and Number Theory), 'Astromundus' (Astronomy and Astrophysics), 'Planthealth' (Plant Health in Sustainable Cropping Systems), 'Medfor' (Mediterranean Forestry and Natural Resources Management), 'Nuphys' (Nuclear Physics), 'Stede' (Sustainable Territorial Development), 'Sufonama' (Sustainable Forest and Nature Management), 'Sutrofor' (Sustainable Tropical Forestry), 'Tpti' (Techniques, Patrimoines, Territories de l'Industrie).

The total number of Chinese students attending the joint Masters Degree and Doctorate courses at UP in the frame of the 'Erasmus Mundus' Actions from 2009 to 2017 amounted to 33 units.

As for Ca' Foscari University of Venice (UCFV), it cooperates with Chinese Universities offering courses of Italian Language to Chinese students visiting UCFV through the 'Marco Polo' and the 'Turandot' Programs: these courses take place at the 'School for International Education' (SIE), a School dedicated to international students.

The School of Economics and Finance hosts the following 'Erasmus Mundus Programs':

a 'Double Degree' in 'Economy, Econometrics and Finance (MEEF)', in cooperation with the Université Aix-Marseille (France). Upon finishing the formative course, selected students will obtain an academic 'double degree': the 'Masters Degree in Economics and Finance' from Ca' Foscari University and the 'Masters Degree en Sciences Economiques (Parcours Econométrie Bancaire et Financière)' from the Université Aix-Marseille;

a 'Joint Masters Degree' in 'Models and Methods in Economics and Management - Erasmus Mundus (QEM)' in collaboration with the Université Pantheon - Sorbonne - Paris 1 (France), the Universität Bielefeld (Germany) and the Universitat Autònoma - Barcelona (Spain).

a 'Double Masters Degree' in 'Economie et Ingénierie Financière (MEF)' by the Université Paris-Dauphine (Francia).

The quota of non-EU students residing abroad consists of 40 places, of which 10 are reserved to Chinese students utilizing the Marco Polo Program.

\section{Conclusions}

The main question posed in the Introduction of this research was the following: 'Were the recent Chinese and Italian personnel reforms of public universities successful in creating the premises for a competitive knowledge production?' Our answer is very positive, both for China as for Italy. The remarkable financial investments by the Chinese central and regional authorities are paying off, contributing to the technological advancement of the Country. The management autonomy enjoyed by the Chinese 'national universities' has encouraged their governing bodies to introduce selective personnel reforms attracting some of the best Chinese scholars, who had before studied and worked abroad. As for the Italian personnel reforms of public universities, the new administrative rules introduced through the 'Gelmini University Law' resized the 'Humboldtian model' of freedom of teaching and researching which inspired the academic activities in the past. The unsolved problem of Italian public universities is the shortage of funds for personnel and research. Public investments in higher education decreased in most countries of the EU after the economical crisis of 2008. Overall the data confirm that the financial situation of higher education in the South of the EU was under extreme pressure during the period 2008-2015 (Katsarova, 2015, 16-17), but it is now slowly improving, as far as Italy is concerned, according to the Italian Institute of Statistics ("Italy's Economic Outlook for 2017-2018", 2018). It seems that the Chinese and the Italian higher education systems are following 'complementary schemes': Chinese universities enjoy a larger management autonomy and higher amounts of financial investments in applied research than the Italian public universities, but preferably strategic research areas are encouraged by the central government with respect to others, according to a top-down strategy. On the contrary 
the Italian 'Ministry of Education, University and Research' grants larger freedom for research to the academic/technical staff, but does not invest enough money in it.

In spite of the shortage of funds of Italian universities, their vitality is evidenced by the significant international cultural cooperation activities which they perform. As Mr. Chen Zhu, vice-chairman of the Standing Committee of the National People's Congress of China, recalled on the occasion of the $15^{\text {th }}$ edition of the "China in the 21 st Century Forum', held in Rome on 23th September 2017 ("China, Italy eye deeper cultural exchange", 2017), 'about 20,000 Chinese students have gone to Italy, and more than 5,500 Italian peers have studied in China, since the 'Marco Polo Project' was launched in 2005, and the 'Turandot Project'. for art education in 2009: in 2016 alone, more than 4,800 young Chinese came to Italy to study.'

Italians are famous for their creativity, not only in Fine Arts, Design, Food Sciences, but also in Science and Technology: let us recall Galileo Galilei (1564-1642), who initiated the scientific revolution when he was professor of Physics and Mathematics at the University of Padova and, some centuries later, Gregorio Ricci Curbastro (1823-1925), professor of Mathematics at the same University, who developed the 'Absolute Differential Calculus', better known as 'Tensor Calculus'. His pupil Tullio Levi Civita, professor at the same university, cooperated with Albert Einstein, at the beginning of last century, in the mathematical definition of the General Theory of Relativity (Heilbron, 2003). The present cultural cooperation activities between China and Italy constitute a challenging issue, engaging both parties with the maximum commitment. This cooperation will require an appropriate time to give its fruits, beneficial to both countries. The slow but steady improvement of the economic conditions of Italy since 2016 will eventually allow a substantial increase of the governmental funding in academic teaching and research activities: let's hope for the best.

\section{References}

Barzelay, M. (1999). How to argue about the New Public Management”. International Public Management Journal, 2(2), 183-216. https://doi.org/10.1016/S1096-7494(00)89035-2.

Cai, Y., \& Liu, C. (2015). The roles of universities in fostering knowledge-intensive clusters in Chinese regional innovation systems. Science and Public Policy, 42(1), 15-29. https://doi.org/10.1093/scipol/scu018

Cantor, N.F. (1993). The Civilization of the Middle Ages. Harper Collins Publishers, New York

"China, Italy eye deeper cultural exchange" (2017, September 26). China Daily, p.11.

Etzkovitz, H. \& Leydesdorff, L. (1995). The Triple Helix: University -Industry -Government Relations: A Laboratory for Knowledge-Based Economic Development. EASST Review, 14,14 - 19.

European Regional Development Fund. (2014). University Spin-offs in China, 1-22. Retrieved from http://www.ladec.fi/filebank/2640-Chinese_universities_spin_off_final.pdf.

Evans, R. (1995). Deng Xiaoping and the Making of Modern China. (2nd ed.). Penguin Books, London, UK.

Fairbank, J.K. (1992). China: A New History. Cambridge, Massachusetts, Harvard University Press.

Federazione Lavoratori della Conoscenza- CGIL. (2018, January 5). Concorsi Università Ottobre 2016 - Gennaio 2018. Retrieved on January 4, 2018 from http://www.flcgil.it/search/query/Concorsi_università_in_Gazzetta_Ufficiale/channel/universita/model/notizia-n azionale-14/sort/latest.

Ministero dell'Istruzione, dell'Università e della Ricerca. (2011). Norme in materia di organizzazione delle università, di personale accademico e reclutamento, nonché delega a Governo per incentivare la qualità e l'efficienza del sistema universitario. Legge n. 240 del 30/12/2010.

Guan P.J. (2015). Personnel System Reform of Universities and Development of Teachers. Beijing Normal University Publishing Group, Beijing, P.R. China.

Guangzhou University Report. (2017). Guangzhou, P.R.China. Retrieved from: http://english.gzhu.edu.cn/, July 2017.

Guangzhou Daxue. (2015). Nianjian (Yearbook). Guangzhou, P.R. China.

Heilbron, J. L., editor. (2003). The Oxford Companion to the History of Modern Science. Oxford University Press, UK.

Holden, K. (2015). The globalization of universities and science in Southern China. Retrieved from: https://www.sciencemag.org/careers/features/2015/06/globalization-universities-and-science-southern-china. 
"Italy's Economic Outlook for 2017-2018". (2018). Istituto Italiano di Statistica Roma. Retrieved from https://www.istat.it/it/archivio/205884, November 2017.

Jones, L.R., Guthrie, J., Steam, P. (2001). Learning from International Public Management Reform. Elsevier Science Inc., Amsterdam, the Netherlands. https://doi.org/10.1108/S0732-1317200111A

Katsarova, I. (2015). Higher Education in the EU. European Parliament Research Service, Bruxelles, March 2015, 16-17, Bruxelles, Belgium.

Li, K. Q. (2014). Personnel Management Regulations of Public Institutions. Decree No. 652 of the State Council of the PRC, Beijing, P.R. China.

Li, L. (2004). China’s Higher Education reform 1998-2003: A Summary. Asia Pacific Education Review, 5(1), 14-23. https://doi.org/10.1007/BF03026275

Li, M. \& Yang, R. (2014). Governance reforms in higher education: a study of China. IIEP Research Papers, UNESCO, 1-54.

Lorange, P. (2015). Strategic Human Resource Management in the Chinese context. Swiss RE, Centre for Global Dialogue.

Ministero dell'Istruzione, dell'Università e della Ricerca. (2011, 14 Gennaio). Norme in materia di organizzazione delle università, di personale accademico e reclutamento, nonche' delega al Governo per incentivare la qualità e l'efficienza del sistema universitario. Legge 30 Dicembre 2010. Gazzetta Ufficiale. Istituto Poligrafico dello Stato, Roma.

Ministero dell'Istruzione, dell'Università e della Ricerca. (2011, 3 Novembre). Le Leggi di Stabilità. Gazzetta Ufficiale. Decreto Ministeriale n. 439, Istituto Poligrafico dello Stato, Roma.

Ngok, K. \& Guo, W. (2008). The Quest for World-Class Universities in China: critical reflections. Policy Futures in Education, 6(5). https://doi.org/10.2304/pfie.2008.6.5.545

Pan, S. Y. (2009). University autonomy, the state and social change in China. Hong Kong University Press, 1-264, Hong Kong, P.R. China.

Sun Yat-Sen University. (2017). University Report. Guangzhou, P.R. China. Retrieved from: http://www.sysu.edu/2012/en/about01/index.htm, October 2017.

Tsui, A., S. (2006). Contextualization in Chinese Management Research. Management and Organization Review, 2(1), 1-13. https://doi.org/10.1111/j.1740-8784.2006.00033.x

Tsui, A., S. (2007). Management research in the academy and beyond. Academy of Management Journal, 50(6), 1353-1364. https://doi.org/10.5465/AMJ.2007.28166121

Università Ca' Foscari di Venezia. (2017, July). Rapporto Annuale del Nucleo di Valutazione di Ateneo per l'A.A. 2015-16. Retrieved from http://www.unipd.it.

Whetten, D.A. (2009). An examination of the interface between Context and Theory applied to the Study of Chinese Organizations. Management and Organization Review, $29-55$. https://doi.org/10.1111/j.1740-8784.2008.00132.x

Wu, G. (2015). China's Party Congress: Power, Legitimacy, and Institutional Manipulation. Cambridge, UK: Cambridge University Press. https://doi.org/10.1017/CBO9781139976800

Xiao, X. A. \& Xiao B. (2013). How the Government influence the change of the personnel system in Chinese Universities. Public Administration in the time of Regional Change", ICPM 2013, Atlantis Press, $229-232$. Retrieved from www.atlantispress.com/php/preface.php?publication=icpm-13, July 2016. https://doi.org/10.2991/icpm.2013.42

$\mathrm{Xu}, \mathrm{C}$. (2011). The Fundamental Institutions of China's Reforms and Development. Journal of Economic Literature, 49(4), 1076-1151. https://doi.org/10.1257/jel.49.4.1076

Yuan, Y. \& Cai, X. (2015). A management scheme for the universities' reform on Human Resource Management and Development in China. International Conference on Social Science and Higher Education, 151-154, Sanya, P.R. China.

Zang, J. (2014). Developing excellence: Chinese university reform in three steps. Nature, 514, $295-296$. https://doi.org/10.1038/514295a 
Zhonghua Renmin Gongheguo Jiaoyubu (Ministry of Educationof the People's Republic of China). (2009). Nianjian (Yearbook) 1984-2009, People's Education Publishing House, Beijing, P.R. China.

Zhou, L. \& Xu, B. (2015). Current condition of the diversification among university, faculty member posts and a political advice: taking the Zhejiang University as an example. Modern Enterprise Education, 2, 98.

\section{Appendix}

\section{A1. Structure and statistical data concerning the Sun Yat-Sen University (SYSU)}

SYSU has 4 Campuses (two campuses inside the city of Guangzhou, one in Zhuhai and one in Shenzhen) and is subdivided into 47 Departments and Schools, distributed in the various campuses.

In 2017 the university staff amounted to 16,849 units. The total number of students amounted in to 74,436 of whom 21,385 were postgraduate students and 5,302 Ph.D. students The research centers in Science and Technology amounted to 80 units, the Medical Research Centers amounted to 98 units and those in the areas of Humanities and Social Sciences amounted to 120 units. As for the scientific research activity at SYSU, it is very innovative in the technological area.

The Departments located in the Guangzhou campuses are the following: Department of Chinese, Department of History, Department of Philosophy, Department of Physical Education, Department of Psychology, Department School of Stomatology, Liberal Arts College, Lingnan College, School of Chemistry, School of Civil Engineering, School of Communication and Design, School of Software, School of Microelectronics, School of Engineering, School of Environmental Science and Engineering, School of Foreign Languages, School of Geography and Planning, School of Government, School of Law, School of Life Sciences, School of Marxism, School of Material Science and Engineering, School of Mathematics, School of National Secrecy, School of Nursing, School of Physics, School of Public Health, School of Sociology and Anthropology, Sun Yat-sen Business School, Zhongshan School of Medicine.

The Departments located in the Zhuhai Campus are the following: Department of Chinese (Zhuhai), Department of History (Zhuhai), Department of Philosophy (Zhuhai), International School of Business and Finance, School of Atmospheric Science, School of Chemical Engineering and Technology, School of International Relations, School of International Studies, School of Marine Sciences, School of Mathematics, School of Physics and Astronomy, School of Tourism and Management, Sino-French Institute of Nuclear Engineering and Technology.

The Departments located in the Shenzhen Campus are the following: School of Aeronautics and Astronautics, School of Biomedical Engineering, School of Electronics and Communication Engineering, School of Intelligent Systems Engineering, School of Pharmaceutical Sciences (Shenzhen), School of Public Health (Shenzhen), School of Marine Engineering and Technology, School of Materials, School of Medicine.

SYSU has also 8 'affiliated hospitals': The First Affiliated Hospital, The Sun Yat-sen Memorial Hospital, The Third Affiliated Hospital, the Zhongshan Ophthalmic Center, the Cancer Centre, the Hospital of Stomatology, the Fifth Affiliated Hospital, The Sixth Affiliated Hospital (Gastrointestinal Hospital), The Seventh Affiliated Hospital (Shenzhen), The Eighth Affiliated Hospital (Futian, Shenzhen).

As for Research and Internationalization at SYSU in 2016, the research institutes active in the areas of Science and Technology amount to 80 units and 155 international cooperation agreements have been established, the greatest number of which with the United States of America ( 28 units), followed by France ( 24 units), Japan and South Korea (19 units with each one) and Australia (9 units). The Medical Research Centers amount to 98 units,

The research institutes in the area of Humanities and Social Sciences (ranging from Accounting to Anticorruption Studies, Chinese Teaching, Classic Studies, Contemporary Literature, Corporate Governance, Economy and Finance, Foreign Languages and Cultures, History and Historical Anthropology, Industrial and Regional Development, Law, Logic and Cognition, Marxist Philosophy, Management, Marketing, Migration and Ethnicity Studies, Overseas Chinese Affairs, Paleography, Philanthropy, Practical Philosophy, Public Administration Research, Religion Studies, Social Sciences, Teaching and Teacher Training, Virtual World Research etc.) amount to 120 units.

\section{A2. Structure and statistical data concerning the Guangzhou University (GZHU)}

GZHU is a comprehensive, municipal/provincial higher education institution, with over 23,000 students (subdivided into undergraduate students, Masters students, Professional Masters students and Ph. D. students), and an academic staff of 1439 units, of whom 290 are full professors, 604 associate professors and the remaining parts are assistant 
professors and researchers. distributed the following Schools and Departments: School of Architecture and Urban Planning (Architecture, Environment Design Orientation, City Planning, Landscape Orientation), School of Basic Education, School of Business (Business Administration, Electronic Commerce, Engineering Management, Human Resource Management, Logistics Management, Marketing), School of Chemistry and Chemical Engineering (Chemical Engineering, Chemistry, Food Science and Engineering), School of Civil Engineering (Building Environment and Energy Utilization Engineering, Civil Engineering, Traffic Engineering, Water supply and Drainage Science, and Engineering), School of Computer Science and Education Software (Computer Science and Technology, Network Engineering, Software Engineering), School of Continuing Education, School of Economics and Statistics, School of Education (Teachers School) (Applied Psychology, Educational Technology, Pedagogy \& Chinese Teaching in Primary School, Pre-school Education, Teacher Education), School of Electro-Mechanical Engineering (Mechanical Design, Manufacture, and Automation, Mechanical Design, Manufacture, and Automation, Electronic Information Engineering, Electrical Engineering and Automation, School of Environmental Engineering (Environmental Engineering, Environmental Science), School of Fine Arts and Artistic Design (Visual Communication Design, Painting, Environmental Design, Fine Arts, Product Design, Clothing and Fashion Design, Animation), School of Foreign Studies (French, English and Japanese Languages), School of Geographic Sciences (Geographic Information Education, Geographic Science Education, Human Geography \& Urban and Rural Planning, Physical Geography and Resource Environment), School of Humanities (Chinese Language and Literature, History, Teaching Chinese as a Foreign Language), School of International Education, School of Journalism and Communications (Advertising, Broadcasting Science, Radio and Television Broadcasting, Radio-TV Program Production and Direction), School of Law, School of Life Sciences (Biological Engineering, Biological Sciences, Biotechnology), School of Mathematics and Information Sciences (Information and Computing Science, Information Security, Mathematics and Applied Mathematics), School of Modern Industry, School of Music and Dance (Choreography, Musicology), School of Physical Education, School of Physics and Electronic Engineering (Electronic Information Science and Technology, Optoelectronic Information Engineering, Physics), School of Politics and Civic Education, School of Public Administration (Administrative Management, Management of Public Services, Social Work), School of Teacher Training.

In what refers to the research activities, GZHU has 57 'Research Centers', through which it is actively undertaking international, national and provincial research programs. It established, among others, the 'Earthquake Engineering Research and Test Center' and the 'Institute of Advanced Manufacturing Technology'. The University established also more than 13 Research Centers in the areas of Higher Education, History, Local Culture and Art, Sociology.

\section{A3. Structure and statistical data concerning the University of Padova (UP)}

UP is subdivided into the following Departments: Department of Agronomy, Food, Natural Resources, Animals, and the Environment, Department of Biology, Department of Animal Medicine, Production and Health, Department of Biomedical Sciences, Department of Cardiac, Thoracic and Vascular Sciences, Department of Chemical Sciences, Department of Civil, Environmental and Architectural Engineering, Department of Comparative Biomedicine and Food Science, Department of Cultural Heritage: Archaeology and History of Art, Cinema, and Music, Department of Developmental Psychology and Socialization, Department of Economics and Management, Department of General Psychology, Department of Geosciences, Department of Historical and Geographic Sciences and the Ancient World, Department of Industrial Engineering, Department of Information Engineering, Department of Land, Environment, Agriculture, and Forestry, Department of Linguistic and Literary Studies, Department of Management and Engineering, Department of Mathematics, Department of Medicine, Department of Molecular Medicine, Department of Neurosciences, Department of Pharmaceutical and Pharmacological Sciences, Department of Philosophy, Sociology, Education, and Applied Psychology, Department of Physics and Astronomy, Department of Political Science, Law and International Studies, Department of Private Law and Critique of Law, Department of Public, International and Community Law, Department of Statistical Sciences, Department of Surgery, Oncology and Gastroenterology, Department of Women's and Children's Health.

In the Academic Year 2016/17 the teaching/research staff amounted to 2,092 units (of whom 445 were Full Professors, 887 Associate Professors, 541 Researchers with tenure and the remaining 179 Researchers with a yearly or triennial employment contract; the yearly contract professors should be added, but their number is difficult to estimate. The total number of students amounted in the same period to 57,404 units, subdivided into Undergraduate Students $(35,227)$, Master Degree Students $(18,569)$, Ph.D. Schools $(1,305)$, Post-Masters Specialization Schools $(1,639)$, Others $(574)$. UP possesses 27 'Interdepartmental Research Centers', whose research activities range from Science and Technology to Medicine, Law and Humanities. 
In what refers to the international cooperation activities of UP, a relevant one is the "HORIZON2020 Cooperation Project", active in the period 2014-2020 inside the universities of EU and structured into 3 "Pillars" ("Excellent Science', 'Industrial Leadership', 'Societal Challenges') and four "Transversal Programs" ('Spreading excellence and widening participation', 'Science with and for Society', 'European Institute of Innovation and Technology', 'Euratom'). Another important group of international cooperations has been made with China, as it will be illustrated in Section 3.2.

\section{A4. Structure and statistical data concerning the Ca' Foscari University of Venice (UCFV)}

UCFV is subdivided into the following Departments: Department of Economy, Department of Management, Department of Environmental Sciences, Department of Computer Science and Statistics, Department of Molecular Sciences and Nano-Systems, Department of Human Sciences, Department of Linguistic Studies, Department of Studies on Asia and Mediterranean Africa, Department of Philosophy and Cultural Goods. In the Academic Year 2016/17 the Academic Staff amounted to 488 units (of whom 129 Full Professors, 223 Associate Professors, 97 Researchers with tenure and 39 Researchers with temporary contract). In the same year the total number of students amounted to 21,557 units, subdivided into Undergraduate Students $(14,800)$, Master Degree Students $(5,617)$, Doctoral Degree Students (315) and students registered in specialization courses (825).

The departmental research activities at UCFV are grouped under the collective title "Research for Global Challenges" and are subdivided into 6 main areas (Science of Complex Economics, Human and Natural Systems, Environmental Technology and Green Economy, Economics and Management of Innovation and Entrepreneurship, Public

Governance, Welfare and Social Innovation, Creative Arts, Cultural Heritage and Digital Humanities, Cross Cultural and Area Studies) and are performed through international partnerships supported by the European Union. 